\title{
The Arc of Complex Global Governance: From Organization to Coalition
}

Miles Kahler

School of International Service, American University, Washington, DC, USA

Council on Foreign Relations, Washington, DC, USA

Paper presented

at

the 2020 American Political Science Association Annual Meeting

10-13 September 2020

The author gratefully acknowledges the research assistance of Frieder Dengler and helpful comments on an earlier draft of this paper by David Coen, Rachel Robinson, Mette EilstrupSangiovanni, Oliver Westerwinter, and participants in the May 2019 and December 2019 workshops on Institutional Complexity in Global Governance at the European University Institute. 


\section{ABSTRACT}

Complex governance challenges the state- and IGO-centric focus in the study of global governance as well as its rational functionalist theoretical perspective. Complex global governance displays a common life cycle across issue areas that have become prominent in the post-Cold War decades: global health, climate change, and efforts to combat illicit financial flows. A transnational coalition expands the agenda of the complex through a political process that advances new issues and widens the agenda's scope. Although national governments and IGOs maintain important roles, resources available to the complex diversify. Governance complexes are able to target behavioral change in actors rather than relying on national governments and their compliance. A common pattern of evolution is enabled by economic and political globalization. Introducing this comparative and dynamic approach to complex global governance permits generalization that is often lacking in distributive approaches to international institutions. This approach also permits an initial estimate of the effectiveness of complex governance and its future sustainability. 


\section{The Arc of Complex Global Governance: From Organization to Coalition Miles Kahler \\ School of International Service, American University \\ Council on Foreign Relations}

\section{Introduction}

Complex global governance in newly emergent issue areas challenges persistent biases in the study of global governance, specifically its state-centric concentration on formal and informal intergovernmental organizations (IGOs). ${ }^{1}$ Although proliferation of IGOs has produced a productive line of research on regime complexes, those examples of complexity have usually been defined as a universe of governance created by states. It has been left to those investigating issue areas such as climate change or global health to illuminate a diversity of governance institutions based on both state and non-state actors, creating an enlarged concept of regime complex. ${ }^{2}$

Theoretically, complex global governance challenges another bias, the rational functionalist view of international institutions as problem-solving products designed by states. As Erik Voeten (2019) has described, this perspective on global governance, which is also state-centric, drains power and conflict from the emergence and maintenance of governance institutions. As an alternative, a distributive view of institutions takes them as sites in which actors aim to advance their private interests rather than solving collective problems of cooperation. Institutions such as international law, for example, provide "tools that states and activists use to pursue their goals" (Hurd 2017: 136). In similar fashion, those surveying recently evolved governance institutions, produced by both state and nonstate actors, find these new forms of governance to be "negotiated settlements and institution-building projects that arise out of conflicts" (Bartley 2007: 299). ${ }^{3}$

Building on and expanding this distributive theoretical perspective, I examine complex global governance over time. In contrast to the rational design perspective, which adopts a static view of bargains among states, I describe a common governance life cycle for issue areas that have risen to prominence on the post-Cold War international agenda. An initial, limited agenda is often centered on an intergovernmental organization, but members of a transnational coalition expand that agenda through a political process, advancing new issues and expanding the scope of the complex. Resources available to the complex diversify, and it becomes less dependent on national governments. The complex develops hybrid forms of governance, usually informal

\footnotetext{
${ }^{1}$ Complex (global) governance is defined as the political process that creates and sustains a set of governance institutions in an issue area. The set of institutions is labeled a governance complex.

${ }^{2}$ For example, Abbott (2012) and Bulkeley et al. (2014).

${ }^{3}$ For a similar view of governance and institutions, Gourevitch (1999).k
} 
or "soft law," either linked to or independent of the older intergovernmental core. New governance formats incorporate private actors, IGOs, and governments, both national and subnational. This common pattern of evolution both reflects and is enabled by economic and political globalization. Introducing this comparative and dynamic element into complex global governance permits generalization that is often lacking in distributive approaches to international institutions, as well as taking seriously the advice that "distributive theories ought to pay attention to history and process rather than just individual bargains" (Voeten 2019: 154).

The emergence of complex governance to combat illicit financial flows (IFFs) shares this life cycle with other institutional ecosystems in the post-Cold War decades. A modest IGO designed to fight transnational crime has become a sprawling coalition that promotes collective action against an expanding list of predicate crimes: drug trafficking, terrorism, corruption, and tax evasion. ${ }^{4}$ I compare the life cycle of this governance complex to two other issue areas that have claimed growing global attention since the end of the Cold War: global health and climate change. Peacebuilding and contemporary trade and investment agreements could also be added to the comparison set. In each of these cases, a snapshot of contemporary global governance appears to reveal a jigsaw puzzle of formal and informal institutions. An examination of change over time, however, reveals instead a layering of one form of governance on earlier ones, often with different combinations of actors, a process that does not weaken or eliminate earlier governance institutions, but transforms their role in global governance.

In tracing the evolution of these governance life cycles over time, I consider five central dimensions in turn: agenda-setting (or issue invention); underlying political coalitions that drive the global agenda and shape complex governance; the persistent yet evolving role of national governments and IGOs; diversification of resources in the complex over time; and an international environment that provides a partial explanation for the emergence of complex governance at a particular historical moment. Following this comparative survey, theoretical questions and policy implications offer guidance for future research on complex global governance. One of these questions concerns the future of complex governance-whether it is an artifact of a particular moment in world politics or a template that will be applied to emerging issue areas.

\section{Agenda-setting and issue creation}

International agenda-setting becomes more competitive and less predictable under conditions of complex governance. The ability to select certain issues for global attention and action and to marginalize others is critical to understanding the power of particular actors within governance complexes. The politics of framing issues - creating issue areas-and establishing linkages among issues are central to the history of governance complexes. A conventional view

\footnotetext{
${ }^{4}$ I have based my account of the IFF governance complex on my Council on Foreign Relations discussion paper, "Countering Illicit Financial Flows: Expanding Agenda, Fragmented Governance" (Kahler 2018).
} 
of agenda-setting may not fully capture the innovation that defines or constructs an issue, serving in turn to define the boundaries of a governance complex. Bentley Allan (2017), for example, describes the constitution of climate itself as a governance object through the interaction of scientific communities and the state.

Over time, the weight of private actors in global agenda-setting has increased. For example, even before the creation of the World Trade Organization (WTO), the international trade agenda reflected the interests of major multinational corporations and financial firms, which are responsible for a large share of global exports, portfolio flows, and foreign direct investment. Their influence is now contested by nongovernmental organizations (NGOs) pressing a contrasting agenda of labor rights and environmental protection, issues that had not previously been incorporated in the trade agenda (Young 2016). In the domains of human rights and human security, NGOs have exploited their positions in wider networks to promote certain issue definitions (Wong 2012; Carpenter 2011; Carpenter et al. 2014). The criteria for elevating some issues and marginalizing others are often only distantly related to more objective measures of global significance or contributions to global welfare.

The agendas of governance complexes are fluid-actors link and detach issues from the complex, at times because of perceived success or a high public profile that attracts others who wish to share in that apparent success. Complex governance agendas widen over time, as new actors respond to a changing environment. Widening, in turn, produces overlap in governance complexes. Trade becomes entwined with labor rights, the environment, and human rights, not only because of the intrinsic linkage among these issues, but also because of trade's attractiveness as a means of enforcement.

\subsection{Global governance to combat illicit financial flows (IFFs)}

Global efforts to combat IFFs exemplify these political processes of agenda-setting and widening over time. Since IFFs are defined by their association with a predicate crime, the process of agenda widening can be tracked by the addition of those crimes to the global IFF agenda. Concern over transnational crime in an era of financial liberalization elevated money laundering to global status: the predicate crimes were widely acknowledged. The agenda widened further-based on a broad global consensus - in the late 1990s to include "combating the financing of terrorism" (CFT). After 9/11, that dimension of the anti-money laundering $(A M L)$ agenda was elevated in importance by the United States and its allies.

Other predicate crimes, however, took longer to be internationalized and incorporated into the governance complex that aimed to combat IFFs. Tax evasion, for example, was initially excluded from the AML agenda. Following passage of the U.S. Foreign Corrupt Practices Act, American efforts to win support for sanctioning bribery of public officials by international corporations were unsuccessful for decades. A broader framing of anti-corruption found its way on to the global governance agenda through the pressure of NGOs; the UN Convention Against Corruption (UNCAC, 2003) confirmed its link to the existing AML/CFT complex. Corruption was at first defined largely as a problem for developing country governments and 
their public sectors. During the first decade of the century, however, the issue was reframed to include the web of enablers located in major financial centers and the behavior of international corporations, particularly those engaged in natural resource extraction. This redefinition of the issue required additional action by industrialized countries.

A final agenda expansion and redefinition occurred during the slow economic recovery from the global financial crisis of 2007-2009. IFFs became linked to the issue of inequality in the industrialized countries, an issue that had risen on domestic political agendas. Tax evasion through the use of offshore financial centers was highlighted through revelations contained in the Panama and Paradise Papers, revelations owed to journalists and NGOs. For the first time, non-criminal behavior - tax avoidance by international corporations-was advanced by some members of the anti-IFF coalition as illicit and requiring international collaboration. That final effort to widen the agenda of the IFF complex, confronting the practices of tax havens and powerful international corporations, was more controversial than earlier additions to the agenda. Efforts to place tax avoidance on the IFF agenda underscored that widening the global governance agenda was far from automatic and dependent on the relative power of actors inside and outside the underlying coalition of support. For different reasons, the United States government (early in the life cycle of this governance complex) and NGOs (in the later agenda expansions) had wielded their influence for a redefined issue, centered a widening of illicit behavior that was linked to cross-border financial flows.

\subsection{Global health governance}

Although global health has a place in international cooperation that dates to the pre-1914 era of globalization, few issue areas have experienced a comparably rapid rise on the global agenda. At the same time, the global health agenda widened dramatically. Jeremy Shiffman (2009) argues that policy communities in global health have established frames that resonate with political elites and other politically influential actors through a process of strategic social construction; they then sustain those frames through the creation of new institutions. The emergence of global health networks - central in the recent governance complex for global health-provide one explanation for the rise of public attention to certain diseases and the relative neglect of others that produce similar burdens on populations (Shiffman et al. 2016).

During the Cold War, the World Health Organization (WHO) remained the dominant actor in global health governance, and two frames competed for support and resources from governments: a "vertical" approach focused on eradicating major infectious diseases and a "horizontal" approach that emphasized improvements in national health systems and public health infrastructure (Clinton and Sridhar 2017: 8-9). These two frames persisted and continued to compete, even as the agenda of the global health complex widened.

The HIV/AIDS epidemic was a shock that confirmed the appearance of a major new global communicable disease and served to promote both a widening of the global health agenda and new linkages to other issue areas. HIV/AIDS was framed as significant for several central foreign policy goals, economic development, human rights, and security (Robinson 2017: 41, 
59-60). As the global health agenda widened, links to other, previously unrelated issue areas were also forged, and international agreements and organizations associated with those issue areas were forced into dialogue and conflict with representatives of the expanding global health coalition. For example, health-related provisions became more common in environmental treaties, growing rapidly during the 1970s, with a peak inclusion ratio in the early 2000s (Morin and Blouin 2019). ${ }^{5}$

Global health governance also intersected with the trade regime. A campaign led by Brazil and South Africa aimed to reform the WTO TRIPS (intellectual property) agreement in order to increase access to anti-retroviral drugs. The agenda of global health, as redefined by these emerging powers and their NGO allies, won a major victory with the adoption of the Doha Declaration (2001) and a protocol amending the TRIPS agreement that was the first amendment to the WTO accords (Gopinathan et al. 2019: 183-184).

Organizations and actors involved in development illustrated the politics underlying a widening global health agenda. HIV/AID was a major precipitant for their move into global health governance. The United Nations Development Program (UNDP), for example, had supported disease-specific programs in the 1980s, but the HIV/AIDS crisis in the late 1980s and 1990s "broadened the organization's engagement with global health" (Gopinathan et al. 2019: 181). The UNDP became a critic of the approach to HIV/AIDS that was led by the WHO and advocated a broader response to the crisis, defining the epidemic as a "multi-sectoral, human rights issue" (lbid.)

With these extensive linkages to other issue areas and organizations, such as trade, migration, and the environment, a more appropriate label for the wider agenda might be "global governance for health" (Frenk and Moon 2013: 939). At the same time, and in keeping with the older vertical agenda in global health, the "revolution in global health governance" (Fidler 2010: 1) also entailed an eventual widening of the global health agenda from communicable diseases, which were the exclusive concern of earlier international efforts, to other threats to health, such as non-communicable diseases, tobacco use, and obesity. The latter, however, have not been able to obtain either the same level of attention or equivalent resources from powerful actors in the global health complex.

\subsection{Climate change}

As in the cases of global governance to combat IFFs and health, the climate change agenda was reframed and widened as it attracted the attention of national political elites and rose in importance on the international agenda. As Bodansky and Rajamani (2018) describe, the first global environmental agenda, which took shape before and after the 1972 Stockholm Conference and the establishment of the United Nations Environmental Program (UNEP),

\footnotetext{
${ }^{5}$ The inclusion ratio is the number of new environmental treaties with health-related provisions divided by the total number of new environmental treaties.
} 
focused on "local, acute, and relatively reversible forms of pollution," which were then gaining political attention in the industrialized world.

Climate change was added to the global environmental agenda during a second period of agenda-setting in the late 1980s, when the issue was transferred from the scientific to the policy domain. A group of scientist-policy entrepreneurs were central in this transformation, leveraging their close ties to the World Meteorological Organization (WMO) and the UNEP. The climate change agenda then became dominated by intergovernmental negotiations, which produced the United Nations Framework Convention on Climate Change (UNFCC) and the Kyoto Protocol. A final stage of agenda widening occurred with the rapid growth of a nongovernmental climate change coalition in the wake of these developments. The agenda of transnational climate governance added forestry and biodiversity, carbon sequestration, and carbon markets and finance to an earlier and more limited focus on energy and low carbon infrastructure (Bulkeley et al. 2014: 30).

\section{Complex governance as coalition formation}

The life cycle of governance complexes can often be identified with shifting and growing coalitions, coalitions that underlie agenda formation and widening. Some institutional components may be explained as a product of rational design, but both governance complexes and constituent institutions of a new type are more plausibly seen as the result of political conflict and contestation. They represent the relative power and interests of different actors with competing or parallel aims, aims that are often stated in the language of global cooperation and welfare. The aims and strategies of the coalition and the priority to be awarded each element in an agenda are contested from within the coalition. Conflict also occurs between these coalitions and those that oppose their aims. Counter-coalitions frame the issue as questioning expert opinion (climate change denial, anti-vaccination), as opposition to government regulation (the alleged regulatory burden of curbing IFFs), or as part of a broader opposition to supranational rules and organizations in the interests of state sovereignty. ${ }^{6}$ The assembly and reassembly of these coalitions and counter-coalitions explains in part the evolution of complex governance arrangements and their ultimate success or failure.

\subsection{Global governance to combat illicit financial flows (IFFs)}

The originating core of governance complexes is often an intergovernmental coalition or transgovernmental network (TGN), although an epistemic or activist community may prompt the first steps toward international collaboration taken by national governments. Global efforts to combat IFFs followed this initial pattern: an informal intergovernmental organization (IIGO), the Financial Action Task Force (FATF, founded 1989) and the standard-setting exercises that it undertook, were the initial instruments deployed against cross-border money laundering, a

\footnotetext{
${ }^{6}$ On conflict within the climate coalition, Hadden (2015). On the formation of a transnational counter-coalition, see Bob (2010).
} 
negative consequence of financial globalization in the 1980 s. $^{7}$ The FATF was complemented by an informal TGN, the Egmont Group, which linked national financial intelligence units in the interests of information and intelligence-sharing. Parallel to the other governance complexes, intergovernmental efforts to combat IFFs were consolidated with a series of UN conventions and the UN Office on Drugs and Crime (1997).

The term "coalition" may overstate the coherence of those political actors who viewed themselves as part of the early governance complex. During the 1990s, and in even more pronounced fashion in the 2000s, actors from outside the state began to press new agenda items and strategies of governance. A first step in the expansion of the anti-IFF coalition enlarged the TGN to enlist additional regulatory agencies, the International Monetary Fund (IMF), and the World Bank in the AML/CFT agenda. The resistance among some of these actors to a program that had been defined as one of law enforcement and national security led to the inclusion of new aims for combating IFFs: the "integrity of the financial system" and "macroeconomic and financial stability" (Reuter and Truman 2004: 140-141).

An even more significant expansion of the coalition came with the mobilization of NGOs (Transparency International, Global Witness) dedicated to a new anti-corruption agenda that in turn defined corruption as a barrier to good governance and economic development. As was the case in climate and global health, these new actors and their growing influence represented both dissatisfaction with national governments and IGOs, long reluctant to break the taboo against including corruption as a development issue, and a growing willingness of governments and IGOs to devolve monitoring and implementation responsibilities to nonstate actors. One explanation for the growing coalition was a marriage of convenience between NGOs competing for resources and higher public profiles on the one hand and, on the other, governments attempting to shed responsibility for difficult and politically contentious issues.

New coalition members expanded the IFF agenda, moving it from a narrower law enforcement focus to linkage with broad global problems, such as development and inequality. Another NGO, Global Financial Integrity, played a lead role in turning attention to the network of enablers for kleptocrats and large-scale corruption. At the same time, divides appeared among the new coalition members over strategy (cooperation with international corporations versus naming and shaming) as well as preferred governance modalities. The final agenda expansion, centering on tax evasion and avoidance, highlighted the importance of another set of actors. Investigative journalists, such as the International Consortium of Investigative Journalists, were able to produce greater transparency in this domain of illicit activity. ${ }^{8}$ At the same time, by linking IFFs to tax policy and its effects on inequality, the focus of governance shifted back to an intergovernmental venue, the G20 and the Organization for Economic Co-operation and Development (OECD), although nonstate actors were deeply involved in the new exercises of standard-setting and peer review.

\footnotetext{
${ }^{7}$ On the formation and operation of FATF, see Reuter and Truman (2004: 81-85); Miller and Rosen (2017).

${ }^{8}$ And these activities were supported by foundations as well as commercial media organizations.
} 


\subsection{Global health governance}

The origins of the global health governance complex were both earlier and more narrowly intergovernmental than global governance in the other two issue areas. Global health appeared on the intergovernmental agenda because of concern over a negative externality of globalized trade in the nineteenth century: the spread of infectious diseases. Other global health issues were also addressed by intergovernmental action in the first half of the $20^{\text {th }}$ century, culminating in the formation of the WHO in 1948 (Fidler 2001). HIV/AIDS, which would contribute to a transformation of the global health agenda, was also addressed initially by the WHO in the 1980s. Additional IGO claimants, among them the UNDP, the United Nations Children's Fund (UNICEF), and the World Bank, eventually cosponsored UNAIDS, which aimed at a more efficient and coordinated response to the epidemic (Robinson 2017: 38-39).

In tandem with the expansion of its agenda, however, global health governance witnessed a transformation of its earlier intergovernmental model. The WHO had endorsed public-private partnerships from its foundation, but the 1990s and 2000s witnessed the entry of new and influential nongovernmental actors who sought to shape global health governance: NGOs, major multinational corporations, biomedical research institutions, and foundations, notably the Gates Foundation. The expansion of the governance coalition was rapid: by the first decade of the $21^{\text {st }}$ century, it was estimated that global health was addressed by "more than 40 bilateral donors, 26 UN agencies, 20 global and regional funds and 19 global-health initiatives" (McColl 2008, cited in Fidler 2010: 14). As a result, the role of the WHO in global health governance has become less central, as more new programs, supported by parts of the coalition, have been situated outside the organization, and governments have directed more of their bilateral aid through NGOs (Fidler 2010: 6). Within the coalition, competing frames emerged. In addition to the original evidence-based medicine, security, human rights, development, and economics rose in prominence (Robinson 2017: 41; Mclnnes and Lee 2012: S193-S194).

New actors also created new hybrid governance arrangements that departed from the intergovernmental model, a "population explosion" that produced a multiplication of processes and principles and a bias toward nonbinding, informal governance arrangements (KoenigAchibugi 2013; Frenk and Moon 2013: 937-938 and Table 1; Fidler 2010: 13). One of the most influential new institutions, the Global Fund to Fight AIDS, Tuberculosis, and Malaria, exemplified the new model, with a board that included representatives of IGOs, the private sector, foundations, NGOs, and communities affected by the disease. It required Country Coordinating Mechanisms that had similar representation.

\subsection{Climate Change}

In global efforts to address climate change, transnational governance grew, but remained largely state-centered during the 1990s. During the 2000s, the climate governance complex witnessed an "explosion of initiatives for governing climate change" (Bulkeley et al. 2014: 6364). After the adoption of the Kyoto Protocol, a more diversified set of actors produced a 
second period of growth in new forms of governance, based on a much broader and heterogeneous coalition. The climate change coalition differed from the other two cases in its move toward polycentric governance - the inclusion of subnational governments as active members of transnational networks of advocacy and action (Jordan et al. 2015: 979). Although a loose counter-coalition of firms in hydrocarbon industries and political jurisdictions dependent on those industries also appeared, the climate change coalition had become so broad that it was sometimes difficult to determine which actors were not in the coalition. For example, central banks have been protective of their independent status and were initially reluctant to sign on to global agendas outside a narrow framing of their mandates. They have now joined the calls for action on climate change, creating a TGN, the Network for Greening the Financial System (Carney 2019). As in other governance complexes, new coalition members often operated through the creation of non-binding arrangements, rather than lobbying for policies that would be legally binding at either the national or global levels (Jordan et al. 2015: 978).

\section{The persistent role of national governments and IGOs in complex governance}

Although the addition of new actors and hybrid governance appeared to diminish the role of national governments and IGOs in each governance complex, the original core of intergovernmental negotiation and organization was not superseded or submerged by new coalition members or governance initiatives. As each of these issue areas demonstrates, the interaction between the intergovernmental core of the complex and other actors and constituents is an important driver of the evolution of these governance complexes.

At least four central roles of national governments and IGOs sustain their position within complex governance:

- Orchestration: Governments and IGOs may actively influence and coordinate other members of the coalition through orchestration and other strategies, such as the provision of funding (Abbott et al. 2015). Hale and Roger (2014) have found a relatively small number of governments and IGOs involved in orchestration in the climate governance complex. Influence runs in both directions: nonstate coalition members also seek to influence governments and IGOs.

- Information: Governments and IGOs may possess information that is not readily available to other members of the coalition: scientific and technical data (important for climate and global health) or intelligence regarding illicit activities (necessary for combating IFFs). The balance of information advantage may shift over time.

- Legitimacy: IGOs and international agreements, particularly those with large memberships, award legitimacy to the agendas of governance complexes and elevate some agenda items over others. United Nations conventions have played that role throughout the history of global governance to combat IFFs. The incorporation of language regarding IFFs in the recent Sustainable Development Goals was regarded as a 
distinct advance within the anti-IFF coalition. ${ }^{9}$ Governance arrangements by nonstate actors may also borrow from the rules created by formal intergovernmental agreements (Green 2013, 2014).

- Enforcement: National governments and courts remain central actors in legal enforcement within governance complexes. Even a highly developed complex that appears entirely private, such as commercial arbitration, hinges on an international convention that commits national courts to the enforcement of private arbitration decisions (Stone Sweet and Grisel 2017; Hale 2015).

\subsection{Global governance to combat illicit financial flows (IFFs)}

The governance complex to combat IFFs demonstrates clear interaction over time between state and nonstate actors within the coalition. NGOs pressed the anti-corruption agenda in the early 1990s. James Wolfensohn, president of the World Bank, then broke the Bank's taboo against addressing corruption in 1996, by enlisting the Bank in the fight against the "cancer of corruption" (Wolfensohn 1996). With corruption placed squarely on the official development agenda by the World Bank, the UN Convention Against Corruption followed (2003); that convention in turn had an explicit link to the UNCAC Coalition, a network of more than 350 NGOs across more than 100 countries, a model of partnership that foreshadowed the Paris Agreement. Sharman (2017: 40-41) argues that this "corruption eruption" cannot be attributed to NGOs, despite their continuing prominence in the IFF coalition: "In terms of timing and support, governments have led NGOs at least as often as the other way around."

Enforcement of AML measures has evolved to include both public and private actors. In this sector and in certain environmental domains, NGOs have undertaken direct enforcement through investigation and private prosecution (enabled by new legislation) through the court system (Eilstrup-Sangiovanni and Bondaroff 2014; Eilstrup-Sangiovanni and Sharman 2019). In countering IFFs, the first line of defense often lies with private financial institutions that monitor and flag illicit financial transactions. Their prominent role in the complex, however, is imposed by national governments and regulatory authorities, backed by the threat of sanctions. An indirect, market-based mode of enforcement occurs through private financial markets, which support FATF's listing of noncompliant jurisdictions by restricting access to international capital (Morse 2019). What has emerged is a system of "pluralized and decentralized transnational enforcement" (Eilstrup-Sangiovanni and Sharman 2019: 4).

\subsection{Global health governance}

Global health did begin with the same architecture of international agreements that characterized either global governance to combat IFFs and many environmental issue areas.

\footnotetext{
${ }^{9}$ Target 16.4 aims to "by 2030, significantly reduce illicit financial and arms flows, strengthen the recovery and return of stolen assets and combat all forms of organized crime," and target 16.5 aims to "substantially reduce corruption and bribery in all their forms."
} 
Despite its emergent complex ecosystem, the WHO, other multilateral organizations, and associated networks of national agencies (such as the U.S. Centers for Disease Control and Prevention) remain core elements in global health governance (Frenk and Moon 2013). Legalized international agreements have come to play a significant role in the global health landscape. The Framework Convention on Tobacco Control (FCTC) was the first WHO adoption of a treaty under Article 19; the International Health Regulations, strengthened in 2005, have been described as "one of the most radical governance innovations" in the history of global health diplomacy (Fidler 2010: 7). As in global governance to combat IFFs, a new division of labor has emerged that presents IGOs, such as the WHO, with a "more complicated, competitive, and difficult" environment, but continues to award them a prominent role in "analyzing problems, designing solutions, and facilitating negotiations" (Fidler 2010: 10-11). As the principal universal membership organization concerned with global health governance, the WHO retains an ability to award global legitimacy that is unmatched by other members of the global health coalition.

\subsection{Climate change}

International cooperation to mitigate climate change lacked the formal organizational core represented by the WHO in global health; even the less formal FATF, which provided an intergovernmental locus in combating IFFs, had no parallel. Member states decided early on that the FCCC would not have a supranational role; it would instead facilitate and coordinate intergovernmental negotiations. Nevertheless, the UNFCC encouraged transnational climate change governance, and the Kyoto Protocol, despite its shortcomings in inducing governments to arrest climate change, by its "mere existence . . . changed the political and economic landscape," spurring activity by nongovernmental members of the climate coalition (Bodansky and Rajamani 2018). The interaction between intergovernmental agreement on the one hand and the coalition of nonstate and subnational actors that grew rapidly in the 2000s on the other was formally confirmed in the architecture of the 2015 Paris Agreement (Bulkeley et al. 2014: 64; Held and Roger 2018: 533).

\section{Resource flows and governance complexes}

In applications of organizational ecology to global governance, the resource environment defines populations of organizations and ecological niches (Abbott, Green and Keohane 2016: 257). Governance complexes vary in their resource requirements. When defined in terms of organizational budgets, global health appears far more resource intensive than anti-IFF global governance or climate governance. Reliance on resource flows at the global level may not capture the entire dedication of resources to governance in a particular issue area, however. For example, enforcement of measures taken against IFFs remains largely at the national level; the resources required of private financial institutions for monitoring financial flows and identifying illicit transactions is substantial, on the order of major U.S. law enforcement agencies (The Clearing House 2017: 3). Capturing resources dedicated at the national and subnational levels to fulfilling global governance mandates is a difficult accounting exercise. In similar fashion, delving inside either private corporations or NGOs to determine shifts in 
budgetary allocations for either adaptation to or mitigation of climate change, including advocacy efforts, would be difficult. It is reasonable to assume that actors joining the coalitions that underlie governance complexes will expend more resources on the issue in question than they had before their engagement.

Resource flows within governance complexes may demonstrate both the growing influence on agendas by actors armed with substantial new resources as well as the blurring of lines between actors of different types that are linked by those resource flows. Both of these changes - resources shaping agendas and blurring of the line between public and private-are dramatically apparent in global health governance. Development assistance for health (DAH) grew rapidly after the 1970s, with an acceleration in its rate of growth from the late 1990s. By the early 2000s, DAH represented 13 percent of all bilateral official development assistance (ODA). At the same time, the sources of DAH shifted dramatically: bilateral aid provided more than 56 percent of DAH in 1990; by 2014, after a five-fold increase in DAH in real terms, more than 20 percent was provided by nonstate actors. A category unknown in 1990-public-private partnerships (PPPs) - added an additional 16 percent (Youde 2017: 593). These innovations in global health governance involve "financial and/or in-kind commitments from nonstate actors such as corporations or foundations to enhance public projects" (Clinton and Sridhar: 13).

PPPs are only one example of the porous boundaries between sources of funding in the global health governance complex. The budgets of philanthropic foundations, such as the Gates Foundation and the Wellcome Trust, rival the resources of the WHO, and the WHO itself receives substantial funding from the Gates Foundation (Koenig-Archibugi 2013: Figure 10.3, 190; Frenk and Moon 2013: Table 1, 938). The pattern is replicated in other development and relief complexes: UNICEF received nearly one-third of its income from private donors (Stroup 2016: 5). National aid agencies (including those dedicated to health programs) increasingly use their resources to support implementing NGOs and private contractors. In 2018, although the U.S. and the U.K. remained important sources of DAH, the largest channel of funding was NGOs (IHME 2018: 14, Figure 9, 51). The web of resource transfers and its less visible consequences for national and subnational budgets represent a challenging target for future investigation in this and other governance complexes.

\section{Variation in the targets of governance}

Governance aims to change the behavior of actors in the near or longer term. In order to achieve a specified aim, a governance complex may adopt a variety of strategies that target different actors. Heterogeneity of actors is a hallmark of complex global governance. Differentiation among the targets of governance, which may also change over time, is an equally important characteristic.

Originally, governance complexes targeted national governments, aiming for cooperative agreements that would shift their policy trajectories over time. Typically, international agreements were forged that required governments to commit to measurable targets (climate) or new domestic legislation or standards (health, countering IFFs). The causal relationship 
between the international agreement and the eventual global outcome was often ill defined. If they were in compliance, national governments, through their own legislation and enforcement, were assumed to further the intended international goals.

The flaws in this approach have been demonstrated in global efforts to combat IFFs. A onesize-fits-all regulatory template was applied at considerable cost to developing economies that were often a minor source of IFFs. International conventions, such as the UNCAC, have weak or non-existent monitoring mechanisms. The ultimate targets of global efforts can only be captured with the cooperation of private actors, and, as the recent Danske Bank scandal has revealed, private financial institutions that reap handsome profits from financial flows often have little incentive to inquire as to their source. National regulators may choose to ignore such behavior rather than question politically powerful (and profitable) actors.

Governance complexes, with their diverse actors and strategies, offer more opportunities to target a wider array of actors directly, rather than relying solely on the capacity and willingness of national governments to enforce. Ideally, these new governance formats provide "different regimes purpose-built for specific challenges" (Fidler 2010: 9). Or, as outlined by Bernstein and Cashore (2012), complex governance can encourage different pathways of influence, rather than exclusive reliance on the route of hard treaty law and compliance imposed on (and by) national governments. New modes of governance that incorporate nongovernmental actors can also be designed to circumvent blockages that result from stalemated international negotiations and recalcitrant national governments.

The political process of constructing complexes over time, however, does not guarantee that such a beneficial and efficient division of labor will emerge. National governments and private actors that are not responsive to international pressure can thwart new forms of governance as they did the old. For example, in the case of extractive industries, multi-stakeholder arrangements, such as the Extractive Industries Transparency Initiative (EITI), rely on robust civil society organizations to monitor the behavior of governments and the bargains that they strike with multinational mining and oil companies. In authoritarian political settings that are characteristic of many resource-rich states, local NGOs and investigative journalists are unlikely to pierce a regime's opaque policymaking.

\section{Changes in the international environment and the evolution of complex global governance}

From an organizational ecology perspective, changes in the global environment are likely to provide a starting point for explaining the life histories of governance complexes. The association of these complexes-and the phenomenon of complex global governance-with the second era of globalization is clear, but the precise causal connections to globalization are more difficult to trace. The same reduction in communication and transportation costs that has enabled multinational enterprises to coordinate their activities across national boundaries has also empowered other actors to operate as transnational actors. 
An ideological shift accompanied-and drove-economic opening. Preceding the collapse of the Soviet model, and accelerating after the end of the Cold War, centralized, planned, and public solutions to common problems became less appealing. Ideological preferences for market-based, decentralized, and private (or nonstate) solutions became dominant. That ideological shift is now being questioned, but during the 1990s and 2000s, governance alternatives that were not strictly intergovernmental or dependent on top-down state action were viewed with favor. Each of these governance complexes aimed at more global governance, which implied more regulation, but they often represented a progressive version of neoliberalism in their undercurrent of disenchantment with the Bretton Woods model of intergovernmental cooperation.

A shift toward private resources has also been a feature of each of these governance complexes, most notably in global health. In this regard, their configuration reflects another dimension of the era of globalization: a diminution in the relative role of public finance. An accumulation of wealth has produced pools of private resources that are used to support both transnational coalitions and counter-coalitions, promoting new agenda items. Just as Andrew Carnegie used his vast fortune to promote world peace, Bill and Melinda Gates have directed private resources to parts of the global health agenda and transformed the global health governance complex.

Opportunities for transnational collaboration during the era of globalization coincided with perceptions of new international vulnerabilities and risks, filtered through domestic politics: new infectious diseases, crime and terrorism, and climate change. Such perceptions, which congealed into the programs of governments and NGOs, propelled national governments and nonstate actors to aim for policy change in other national jurisdictions that would reduce or eliminate these risks and produce desired global outcomes. Often these perceived negative externalities did not match "objective" measures of risk and harm, but they could move governance strategies and outcomes, particularly when they were endorsed by powerful states or coalitions of transnational actors.

Globalization also produced periodic shocks that heightened these perceptions of risk: the HIV/AIDS epidemic and recurrent Ebola outbreaks; the terrorist attacks of September 2001 and after, which raised awareness of the reach of violent networks; the global financial crisis of 2007-2009, which produced a simmering resentment of financial and political elites and fueled the emergence of corruption and inequality as a potent political issue. Those shocks served as mobilizing and framing devices for members of the transnational coalitions that supported governance complexes and their evolving agendas.

\section{Conclusion: evaluating and sustaining complex governance}

Complex global governance has become the norm across many issue areas that have risen on the international agenda over the past three decades. Many envisaged the "new world order" after the Cold War as one in which IGOs, dominated by the club of industrialized countries, would manage an increasingly prosperous and peaceful world. That was certainly one part of 
recent history and the origin story of governance complexes. One would not have predicted in 1990, however, that expanding global agendas would be claimed by a far more variegated array of governance alternatives, promoted by enlarged transnational coalitions. One question for future research is how to explain the presence and extent of complex governance in certain issue areas and not in others. That question leads in turn to reflection on why, in the universe of global issues, some frames resonate with elites and publics, producing a governance coalition and complex, and others do not. Such an investigation would require more than an evaluation of why some agenda items are elevated over others. The universe of potential items for global concern would need to be compared to those that eventually receive transnational attention and action.

Each of these governance complexes confirms that global governance agendas are redefined over time as part of a political process. In the case of global governance to combat IFFs, the agenda moved from one that excluded tax evasion to a contemporary one that links IFFs to a widening number of global harms - terrorism, corruption and underdevelopment, tax evasion and rising inequality. At the same time, governance has shifted from implementation by an intergovernmental club of industrialized countries to a global set of conventions and a governance complex supported by public and private actors. The evolution of global health governance and international action to mitigate climate change also follow this pattern.

In the eyes of its proponents and many scholars, complex global governance represents an improvement over the intergovernmental model for reasons that have been advanced by both scholars and members of the governance coalitions: an agenda that changes and widens to deal with a growing list of international ills; an inclusive, and therefore more legitimate, political coalition that enacts and supports new governance alternatives; an ability to circumvent gridlock in intergovernmental organizations and negotiations; governance that is tailor-made for specific problems and targeted to the appropriate agents; new resources that are not dependent on fiscally constrained governments. At the same time, critics have undermined each of these claims. Instead of coherent movements that produce useful collaboration among a widening array of actors, they find a "governance patchwork" that is "fragmented, inefficient, and incapable of producing a convergence of interests, strategies, and resources, which often makes it difficult for developing countries to participate effectively." ${ }^{10}$ Beneath a veneer of democratization in agenda-setting, complexity obscures an erosion of legitimacy, owed to an absence of accountability, and a deficit in achievements.

If a widening agenda capturing more global issues defines success, then most of these governance complexes were successful. An evaluation that defines success by effectiveness in attaining the global outcomes desired by constituents of the governance complex is more difficult. For the governance complex combating IFFs, anecdotal evidence, such as the 1MDB and Danske Bank revelations, suggests a chain of governance with significant gaps-from corrupted national governments to non-compliant banks. Given the illicit nature of these financial flows, estimates of their scale vary widely, making any counterfactual-a world in the

\footnotetext{
${ }^{10}$ Fidler 2010: 12-13, describing expert opinions of global health governance.
} 
absence of these global countermeasures or a world that relied entirely on intergovernmental cooperation-difficult or impossible to estimate (Levi, Reuter and Halliday 2017; Truman 2016). The positive side of the ledger must also be balanced by negative, unintended consequences, such as de-risking that has led to a reduction in banking relations with poor and conflict-prone jurisdictions. The pursuit of precise metrics for evaluation carries its own biases. Vertical campaigns in global health that aim to eradicate particular diseases demonstrate progress that is easily measured. Those programs can divert resources from efforts to build national health infrastructure that are less appealing to donors despite their value for future health outcomes.

A measure of effectiveness that appears more tractable is alteration in the trajectory of national policies (or the behavior of other targeted actors) consistent with the aims of the governance complex. As Bernstein and Cashore (2012: 603) suggest, however, an assessment of this kind is rendered difficult by "the interaction of mechanisms and processes, sometimes along multiple pathways, that create collective influence." Creating mutually reinforcing pathways of influence rather than competitive or counter-productive ones would increase effectiveness by reducing fragmentation and incoherence in a governance complex. A recent study of the interaction of global health governance and policies pursued by African governments indicates a need for clear and consistent international signals coupled with influential civil society organizations, networked to international partners, that exert pressure from below (Patterson 2018: chapter 4). Generalizing such a model has difficult prerequisites: coherent, intelligible goals and strategies on the part of governance complexes, coordination among governance coalition members, and cooperation between the transnational coalition and domestic NGOs in the target states.

This abbreviated history of three governance complexes poses a final question: the sustainability and possible extension of complex governance. Governance complexes have not yet consolidated in some global issue areas, such as cyber, which has a broad agenda, or emerged in others, such as migration, a sensitive domestic political issue that has been closely held by national governments. The current U.S. administration is deeply suspicious of many existing governance arrangements and intent on defining national sovereignty as the absence of cooperative arrangements of this kind; other governments also appear suspicious of the transnational networks that sustain complex governance. Despite the shifting attitudes of governments, however, transnational civil society remains robust, and globalization has not yet gone into reverse.

In certain respects, we are living a natural experiment in global governance. The past three decades may prove to be a passing experiment, to be superseded or undermined, as the League of Nations system was before World War II. On the other hand, governance complexes may remain a prominent feature of world politics, evolving to accommodate the changing political environment, co-existing with and reinforcing international organizations and their national government principals. In evaluating complex governance and predicting its future, it is probably best to adopt the measured optimism of Elinor Ostrom regarding polycentric governance, which shares many features with complex governance: we can accept complexity and aim to facilitate institutions that "bring out the best in humans," asking how these complex 
institutions can help or hinder "the achievement of more effective, equitable, and sustainable outcomes at multiple scales" (Ostrom 2010: 665). 


\section{Bibliography}

Abbott, Kenneth W., Philipp Genschel, Duncan Snidal, and Bernhard Zangl. 2015. "Orchestration: Global Governance through Intermediaries." In International Organizations as Orchestrators, edited by Kenneth W. Abbott, Philipp Genschel, Duncan Snidal, and Bernhard Zangl, 3-36. Cambridge: Cambridge University Press.

Abbott, Kenneth W., Jessica F. Green, and Robert O. Keohane. 2016. "Organizational Ecology and Institutional Change in Global Governance." International Organization 70 (2): 247277. https://doi.org/10.1017/S0020818315000338.

Allan, Bentley B. 2017. "Producing the Climate: States, Scientists, and the Constitution of Global Governance Objects." International Organization 71 (1): 131-162. https://doi.org/10.1017/S0020818316000321.

Bartley, Tim. 2007. "Institutional Emergence in an Era of Globalization: The Rise of Transnational Private Regulation of Labor and Environmental Conditions." American Journal of Sociology 113 (2): 297-351. https://doi.org/10.1086/518871.

Bernstein, Steven, and Benjamin Cashore. 2012. "Complex Global Governance and Domestic Policies: Four Pathways of Influence." International Affairs 88 (3): 585-604. https://doi.org/10.1111/j.1468-2346.2012.01090.x.

Bob, Clifford. 2010. "Packing Heat: Pro-Gun Groups and the Governance of Small Arms." In Who Governs the Globe?, edited by Deborah D. Avant, Martha Finnemore, and Susan K. Sell, 183-201. New York: Cambridge University Press.

Bodansky, Daniel, and Lavanya Rajamani. 2018. "The Evolution and Governance Architecture of the United Nations Climate Change Regime." In Global Climate Policy: Actors, Concepts and Enduring Challenges, edited by Urs Luterbacher and Detlef Sprinz, 2nd ed. Cambridge: MIT Press: 13-65.

Bulkeley, Harriet, Liliana B. Andonova, Michele M. Betsill, Daniel Compagnon, Thomas Hale, Matthew J. Hoffmann, Peter Newell, Matthew Paterson, Charles Roger, and Stacy D. Vandeveer. 2014. Transnational Climate Change Governance. New York: Cambridge University Press.

Carney, Mark. 2019. “Fifty Shades of Green." Finance \& Development 56 (4): 12-15.

Carpenter, Charli, Sirin Duygulu, Alexander H. Montgomery, and Anna Rapp. 2014. "Explaining the Advocacy Agenda: Insights from the Human Security Network." International Organization 68 (2): 449-470. https://doi.org/10.1017/S0020818313000453.

Carpenter, R. Charli. 2011. "Vetting the Advocacy Agenda: Network Centrality and the Paradox of Weapons Norms." International Organization 65 (1): 69-102.

Clinton, Chelsea and Devi Sridhar. 2017. Governing Global Health: Who Runs the World and Why? New York: Oxford University Press.

Eilstrup-Sangiovanni, Mette, and Teale N. Phelps Bondaroff. 2014. "From Advocacy to Confrontation: Direct Enforcement by Environmental NGOs." International Studies Quarterly 58 (2): 348-361.

Eilstrup-Sangiovanni, Mette, and J. C. Sharman. 2019. "Enforcers beyond Borders: Transnational NGOs and the Enforcement of International Law." Perspectives on Politics (First view): 117. https://doi.org/10.1017/S153759271900344X. 
Fidler, David P. 2001. "The Globalization of Public Health: The First 100 Years of International Health Diplomacy." Bulletin of the World Health Organization 79 (9): 842-849.

Fidler, David P. 2010. "The Challenges of Global Health Governance." Working Paper. Council on Foreign Relations.

Frenk, Julio, and Suerie Moon. 2013. "Governance Challenges in Global Health." New England Journal of Medicine 368 (10): 936-942. https://doi.org/10.1056/NEJMra1109339.

Gopinathan, Unni, Nick Watts, Alexandre Lefebvre, Arthur Cheung, Steven J. Hoffman, and John-Arne Røttingen. 2019. "Global Governance and the Broader Determinants of Health: A Comparative Case Study of UNDP's and WTO's Engagement with Global Health." Global Public Health 14 (2): 175-189. https://doi.org/10.1080/17441692.2018.1476567.

Gourevich, Peter Alexis. 1999. "The Governance Problem in International Relations." In Strategic Choice and International Relations, edited by David A. Lake and Robert Powell, 137-164. Princeton: Princeton University Press.

Green, Jessica F. 2013. "Order out of Chaos: Public and Private Rules for Managing Carbon." Global Environmental Politics 13 (2): 1-25.

- - . 2014. Rethinking Private Authority Agents and Entrepreneurs in Global Environmental Governance. Princeton: Princeton University Press.

Hadden, Jennifer. 2015. Networks in Contention: The Divisive Politics of Climate Change. New York: Cambridge University Press.

Hale, Thomas. 2015. "The Rule of Law in the Global Economy: Explaining Intergovernmental Backing for Private Commercial Tribunals." European Journal of International Relations 21 (3): 483-512. https://doi.org/10.1177/1354066114546955.

Hale, Thomas, and Charles Roger. 2014. "Orchestration and Transnational Climate Governance." The Review of International Organizations 9 (1): 59-82. https://doi.org/10.1007/s11558-013-9174-0.

Held, David, and Charles Roger. 2018. "Three Models of Global Climate Governance: From Kyoto to Paris and Beyond." Global Policy 9 (4): 527-537. https://doi.org/10.1111/1758$\underline{5899.12617 .}$.

IMHE (Institute for Health Metrics and Evaluation). 2019. Financing Global Health 2018. Seattle: IMHE.

Jordan, Andrew J., Dave Huitema, Mikael Hildén, Harro van Asselt, Tim J. Rayner, Jonas J. Schoenefeld, Jale Tosun, Johanna Forster, and Elin L. Boasson. 2015. "Emergence of Polycentric Climate Governance and Its Future Prospects." Nature Climate Change 5: 977982.

Kahler, Miles. 2018. "Countering Illicit Financial Flows: Expanding Agenda, Fragmented Governance." Global Governance to Combat Illicit Financial Flows. New York: Council on Foreign Relations. https://www.cfr.org/report/global-governance-combat-illicit-financialflows.

Koenig-Archibugi, Mathias. 2013. "Complexity and Institutional Diversity in Global Health Governance." In Asia's Role in Governing Global Health, edited by Kelley Lee, T. Pang, and Yeling Tan, 179-197. New York: Routledge.

Levi, Michael, Peter Reuter, and Terence Halliday. 2017. "Can the AML System Be Evaluated without Better Data?" Crime, Law and Social Change 69 (2): 307-328. http://dx.doi.org/10.1007/s10611-017-9757-4. 
McInnes, Colin, and Kelley Lee. 2012. "Framing and Global Health Governance: Key Findings." Global Public Health 7 (sup2): S191-S198.

Miller, Rena S, and Liana W Rosen. 2017. "Anti-Money Laundering: An Overview for Congress." CRS Report for Congress 7-5700. Washington, DC: Congressional Research Service.

Morin, Jean-Frédéric, and Chantal Blouin. 2019. "How Environmental Treaties Contribute to Global Health Governance." Globalization and Health 15 (47). https://doi.org/10.1186/s12992-019-0493-7.

Morse, Julia C. 2019. "Blacklists, Market Enforcement, and the Global Regime to Combat Terrorist Financing." International Organization 73 (3): 511-545.

Ostrom, Elinor. 2010. "Beyond Markets and States: Polycentric Governance of Complex Economic Systems." American Economic Review 100 (3): 641-672.

Patterson, Amy S. 2018. Africa and Global Health Governance: Domestic Politics and International Structures. Baltimore: Johns Hopkins University Press.

Reuter, Peter, and Edwin M. Truman. 2004. Chasing Dirty Money: The Fight Against Money Laundering. Washington, DC: Peterson Institute for International Economics.

Robinson, Rachel Sullivan. 2017. Intimate Interventions in Global Health: Family Planning and HIV Prevention in Sub-Saharan Africa. Cambridge: Cambridge University Press.

Sharman, J.C. 2017. The Despot's Guide to Wealth Management: On the International Campaign against Grand Corruption. Ithaca: Cornell University Press.

Shiffman, Jeremy. 2009. "A Social Explanation for the Rise and Fall of Global Health Issues." Bulletin of the World Health Organization 87 (8): 608-613. http://dx.doi.org/10.2471/BLT.08.060749.

Shiffman, Jeremy, Kathryn Quissell, Hans Peter Schmitz, David L. Pelletier, Stephanie L. Smith, David Berlan, Uwe Gneiting, et al. 2016. "A Framework on the Emergence and Effectiveness of Global Health Networks." Health Policy and Planning 31 (suppl_1): i3-i16. https://doi.org/10.1093/heapol/czu046.

Stone Sweet, Alec, and Florian Grisel. 2017. The Evolution of International Arbitration: Judicialization, Governance, Legitimacy. New York: Oxford University Press.

Stroup, Sarah S. 2016. "Organizational Ecology and International NGOs." In Conference on Organizational Ecology and Institutional Change in Global Governance, December 2016. Princeton University.

The Clearing House. 2017. "A New Paradigm: Redesigning the U.S. AML/CFT Framework to Protect National Security and Aid Law Enforcement." New York: The Clearing House.

Tosun, Jale. 2017. "Polycentrism in Global Health Governance Scholarship." International Journal of Health Policy and Management 7 (1): 78-80.

Truman, Edwin M. 2016. "Reflections on Anti-Money Laundering." Remarks. PIIE. June 27. https://www.piie.com/commentary/speeches-papers/reflections-anti-money-laundering.

Voeten, Erik. 2019. "Making Sense of the Design of International Institutions." Annual Review of Political Science 22: 147-163.

Wolfensohn, James D. 1996. People and development : annual meetings address by James D. Wolfensohn, President (English). Presidential speech Washington, D.C. : World Bank Group. http://documents.worldbank.org/curated/en/135801467993234363/People-anddevelopment-annual-meetings-address-by-James-D-Wolfensohn-President 
Wong, Wendy H. 2012. Internal Affairs: How the Structure of NGOs Transforms Human Rights. Ithaca: Cornell University Press.

Youde, Jeremy. 2017. "Global Health Governance in International Society." Global Governance 23 (4): 583-600.

Young, Alasdair R. 2016. "Not Your Parents' Trade Politics: The Transatlantic Trade and Investment Partnership Negotiations." Review of International Political Economy 23 (3): 345-378. https://doi.org/10.1080/09692290.2016.1150316. 